\title{
MICRO-MODIFICATION OF KAOLIN TREATMENT OF SERUM FOR THE RUBELLA HAEMAGGLUTINATION-INHIBITION TEST
}

\author{
S. INOUYE \\ Central Virus Diagnostic Laboratory, National Institute of Health, \\ Musashimurayama-shi, 19012, Japan
}

Most laboratories do the haemagglutination-inhibition (HI) test for rubella serum-antibodies by the " microtitre" technique. Kaolin is commonly used to remove non-specific inhibitors but this pretreatment of the serum is usually done by a conventional macromethod in tubes, requiring $0.2 \mathrm{ml}$ of the test serum (Plotkin, 1969). This report describes a micromethod of kaolin extraction, for which only $0.025 \mathrm{ml}$ of serum is required and in which 96 serum specimens can be treated in a single micro-plate.

\section{Methods}

Micromethod. An $0.025 \mathrm{ml}$ quantity of serum is delivered into a well of a rigid microplate with raised rim (MicroTest II; Falcon Plastics, Oxnard, USA), followed by $0 \cdot 1 \mathrm{ml}$ of a

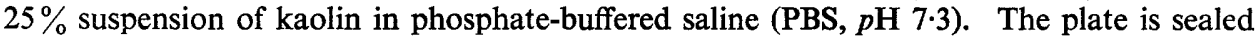
with pressure-sensitive film (Falcon), shaken vigorously by hand and left at room temperature for $20 \mathrm{~min}$. It is then placed on a micro-plate carrier (Cooke Engineering Co., Alexandria, USA) and centrifuged for 3 min. at 1500 r.p.m. in an International model PR-2 centrifuge (International Equipment Co., Needham Heights, USA). The seal is peeled off, and 0.025 $\mathrm{ml}$ of PBS and $0.05 \mathrm{ml}$ of a stock $8 \%$ suspension of goose or 1-day-old chick erythrocytes in dextrose-gelatin-veronal buffer (DGV) are added to the well (the stock suspensions of red cells are stable at $4^{\circ} \mathrm{C}$ for 1 to 2 weeks). The plate is resealed and incubated at $4^{\circ} \mathrm{C}$ for $1 \mathrm{~h}$, with occasional gentle shaking, to remove natural red-cell agglutinins from the serum. After a further period of centrifugation as above, the seal is removed and the treated serum specimen, now regarded as diluted 1 in 8 , is transferred to a fresh microplate by means of a $50 \mu 1$ Eppendorf micropipette (Eppendorf Gerätebau+Hinz GmbH, Hamburg, West Germany) for rubella HI-antibody titration. This was performed by the standard technique (Stewart et al., 1967), in a modified DGV diluent (Inouye and Kono, 1972).

Macro method. To $0.2 \mathrm{ml}$ of serum in a small, round-bottomed tube are added $0.6 \mathrm{ml}$ of PBS and $0.8 \mathrm{ml}$ of a $25 \%$ suspension of kaolin. The mixture is shaken, placed at room temperature for $20 \mathrm{~min}$. and then centrifuged for $20 \mathrm{~min}$. at 2000 r.p.m. to deposit the kaolin. To the supernate in situ is now added $0.05 \mathrm{ml}$ of a $50 \%$ suspension of goose or chick erythrocytes and absorption of natural agglutinins is allowed to occur over $1 \mathrm{~h}$ at $4^{\circ} \mathrm{C}$. After further centrifugation, the supernate, now at 1 in 8 dilution, is removed and titrated for antibody as above.

\section{RESULTS}

Ninety-six serum specimens with rubella $\mathrm{HI}$-antibody titres ranging from 16 to 256 and 20 sera with antibody titres of $<8$ (previously titrated by standard techniques) were treated for removal of non-specific inhibitors by both the micro- and macro-methods. The sera were then titrated for antibody simultaneously in " microtitre" plates. The results from the 96 antibody-positive sera are summarised in the table. No significant differences were found between the titres obtained after pretreatment of the sera by the two methods. All 20 antibody-negative sera were confirmed as negative after both methods of kaolin treatment. 
TABLE

Comparison of rubella haemagglutination-inhibiting antibody titres in 96 sera after kaolin treatment to remove non-specific inhibitors by micro- and macro-methods

\begin{tabular}{c|c}
\hline Number of sera examined & $\begin{array}{c}\text { Range of differences in titre } \\
\left(\mathrm{n}-\mathrm{n}^{\prime}\right)^{*}\end{array}$ \\
\hline 7 & $\begin{array}{r}-1 \\
0 \\
+1 \\
9\end{array}$ \\
\hline
\end{tabular}

* $2^{\mathrm{n}}=\mathrm{HI}$ antibody titre after treatment by micromethod. $2^{\mathrm{n} \prime}=\mathrm{HI}$ antibody titre after treatment by macromethod.

\section{Discussion}

Among the techniques described for removing non-specific inhibitors of haemagglutination from serum, kaolin treatment is still a method of choice (Haukenes and Blom, 1975). The micromethod described here has been shown to be as reliable as the standard macromethod, and at the same time it is technically easier, reducing the time taken to treat large numbers of specimens. There is also a considerable saving on the amounts of erythrocytes used to remove red-cell agglutinins and a further saving of effort since, instead of having to prepare $50 \%$ suspensions of erythrocytes for absorption, as in the macro-method, $8 \%$ stock suspensions can be used directly. A little care is required, however, when removing the treated serum finally from the well with the micropipette, to avoid disturbing the pellet of kaolin and red cells. The micro-procedure should be especially useful for mass surveys of rubella antibody, but it can also be applied to tests for other viral infections.

\section{SUMMARY}

A micromethod of kaolin extraction of non-specific inhibitors from serum is described for the rubella HI-antibody test. It has proved to be as reliable as, and technically easier to perform than, the conventional macromethod.

\section{REFERENCES}

HAUKENES, G. AND BLOM, H. 1975. False positive rubella virus haemagglutination inhibition reactions: occurrence and disclosure. Med. Microbiol. Immunol., 161, 99.

INOUYE, S. AND KoNO, R. 1972. Haemagglutination-inhibiting (HI) antibody response against rubella virus in non-pregnant and pregnant rabbits and transmission of antibody to young. J. Immunol., 108, 370.

Plotkin, S. A. 1969. Rubella virus. In Diagnostic procedures for viral and rickettsial diseases, 4th ed., edited by E. L. Lenette and N. J. Schmidt, New York, p. 364.

Stewart, G. L., Parkman, P. D., Hopps, H. E., Douglas, R. D., Hamilton, J. P. and MEYER, H. M. 1967. Rubella virus haemagglutination-inhibition test. New Engl. J. Med., 276, 554. 